\title{
Potencial forrajero y productividad del agua en patrones de cultivos alternativos
}

\section{Forage potential and water productivity in alternative cropping patterns}

\author{
David Guadalupe Reta Sáncheza, Uriel Figueroa Viramontesa, J. Santos Serrato Coronab, \\ Héctor Mario Quiroga Garzaa, Arturo Gaytán Mascorroa, José Antonio Cueto Wongc
}

\begin{abstract}
RESUMEN
Los sistemas de producción de forrajes se pueden mejorar con la incorporación de especies alternativas con altos atributos nutricionales. El objetivo del estudio fue evaluar el potencial forrajero y productividad del agua (PA) en patrones de cultivos forrajeros que incluyeron canola (Brassica napus L.), chícharo (Pisum sativum L.) y soya (Glycine max L.) como cultivos alternativos. Se compararon los patrones alternativos maíz-maíz-canola, sorgo-sorgo-canola, maíz-maíz-chícharo y soya-maíz-avena con los patrones convencionales, alfalfa, maíz-avena y maíz-maíz-avena. El estudio se realizó de abril de 2009 a abril de 2011 en Matamoros, Coahuila, México. Se determinó la composición química del forraje, los rendimientos de materia seca (MS), nutrientes y PA en la producción de MS, proteína cruda (PC) y energía neta para lactancia $\left(E N_{L}\right)$. La incorporación de canola en los patrones con maíz o sorgo en primavera y verano incrementó el rendimiento de PC (34.4\%) y la PA (33.3 \%), sin disminuir los rendimientos de MS y EN , $_{\text {, }}$ al compararse con el patrón convencional maíz-maíz-avena. Los patrones que incluyeron canola registraron mayores rendimientos de $\mathrm{MS}$ y $\mathrm{EN}_{\mathrm{L}}$, utilizando el $83 \%$ del volumen de agua requerido por alfalfa, pero con menor rendimiento de PC (19 a $25 \%$ ). La PA y el rendimiento de PC se incrementaron en el patrón soya-maíz-avena, pero con menores rendimientos de MS y EN $\mathrm{N}_{\mathrm{L}}$. En los patrones maíz-maíz-chícharo y maíz-maíz-avena los rendimientos de MS y nutrientes y PA fueron similares. Los resultados indican que la incorporación de canola y soya en los sistemas de producción de forrajes incrementa la productividad del agua.
\end{abstract}

PALABRAS CLAVE: Materia seca, Nutrientes, Composición química, Brassica napus L., Pisum sativum L., Glycine $\max \mathrm{L}$.

\begin{abstract}
The forage cropping systems can be improved with the inclusion of high nutritional quality alternative species. The objective of the study was to evaluate the forage potential and water productivity (WP) of forage cropping patterns which included canola (Brassica napus L.), pea (Pisum sativum L.) and soybean (Glycine max L.) as alternative crops. The alternative cropping patterns corn-corn-canola, sorghum-sorghum-canola, corn-corn-pea and soybean-corn-oat were compared with the conventional patterns alfalfa, corn-oat and corn-corn-oat. The study was conducted from April of 2009 to April of 2011 in Matamoros, Coahuila, Mexico. Forage chemical composition, dry matter (DM) and nutrient yields, and WP values for DM, crude protein (CP) and net energy for lactation ( $\mathrm{NE}_{\mathrm{L}}$ ) production were determined. The incorporation of canola into cropping patterns with corn and sorghum sown in spring and summer seasons increased CP yield (34.4\%) and WP (33.3\%) for CP production, without yield decreases in DM and NEL as compared to the conventional cropping pattern corn-corn-oat. The cropping patterns that included canola produced higher $D M$ and $N E_{L}$ yields, using $83 \%$ of alfalfa water requirement, however they had a 19 to $25 \%$ reduction in CP yield. In the cropping pattern soybean-corn-oat, yields and WP of CP were increased, but it produced lower DM and $\mathrm{NE}_{\mathrm{L}}$ yields. In the cropping patterns corn-corn-pea and corn-corn-oat, yields and WP for DM and nutrients production were similar. The results indicate that canola incorporation into forage cropping patterns increases WP.
\end{abstract}

KEY WORDS: Dry matter, Nutrient yields, Forage chemical composition, Brassica napus L., Pisum sativum L., Glycine $\max \mathrm{L}$.

Recibido el 3 de octubre de 2013. Aceptado el 16 de septiembre de 2014.

a Campo Experimental La Laguna, Instituto Nacional de Investigaciones Forestales, Agrícolas y Pecuarias (INIFAP). Blvd. José Santos Valdez 1200. Col. Centro. 27440, Cd. Matamoros, Coahuila. México. Tel. (871) 1823081 reta.david@inifap.gob.mx. Correspondencia al primer autor.

b Facultad de Agricultura y Zootecnia, Universidad Juárez del Estado de Durango. Gómez Palacio, Dgo. México.

c Centro Nacional de Investigación Disciplinaria Relación Agua-Suelo-Planta-Atmósfera, INIFAP. Cd. Lerdo, Durango. México. 


\section{INTRODUCCIÓN}

En el Norte-Centro de México, la leche se produce principalmente en sistemas de producción especializados, los cuales dependen de forrajes bajo irrigación tales como alfalfa, maíz, sorgo y cereales de invierno para nutrir al ganado. En estos sistemas la producción de forraje es limitada por la baja disponibilidad de agua, salinidad en el suelo, alta temperatura ambiental y un número limitado de cultivos forrajeros(1). Por ello, es importante identificar alternativas que permitan incrementar la eficiencia de producción de forraje.

La producción de forrajes y de leche de bovino en la Comarca Lagunera de México es una de las principales actividades económicas del sector agropecuario. La alfalfa con una superficie de 38,771 ha es el principal cultivo proteico la cual se cosecha durante todo el año, y en menor grado los cereales de otoño-invierno (avena y triticale) en una superficie de 19,716 ha; una gran parte de la energía y fibra requerida por el ganado se produce en primavera y verano con los cultivos de maíz y sorgo establecidos en superficies de 27,344 y 26,251 ha, respectivamente(2). La alfalfa, con una lámina de riego anual superior a $2.0 \mathrm{~m}$ produce rendimientos frecuentemente de $20 \mathrm{t} \mathrm{ha}^{-1}$ de MS y $4,400 \mathrm{~kg} \mathrm{ha}^{-1}$ de PC(3), con una PA de $1.18 \mathrm{~kg}$ de MS por $\mathrm{m}^{3}$ de agua aplicada(4). Los principales patrones de cultivo con especies anuales establecidos para los ciclos de primavera, verano y otoño-invierno son maízmaíz-avena y sorgo-sorgo-avena, y en menor grado maíz-avena. El patrón de cultivos con mayor productividad generalmente es maízmaíz-avena, el cual produce rendimientos hasta de $40 \mathrm{t} \mathrm{ha}^{-1}$ de MS, 3,689 $\mathrm{kg} \mathrm{ha}^{-1}$ de PC y de 234,104 megajoules (MJ) ha-1 de $\mathrm{EN}_{\mathrm{L}}$, con una lámina de riego similar a la de alfalfa $(2.0 \mathrm{~m})$. Además, se obtienen valores de PA por $\mathrm{m}^{3}$ de $2.0 \mathrm{~kg}$ de MS, $0.18 \mathrm{~kg}$ de PC y $11.46 \mathrm{MJ}$ de $\mathrm{EN}_{\mathrm{L}}(5)$.

La composición química y rendimiento de forraje de especies alternativas como canola, chícharo

\section{INTRODUCTION}

In the North-Central Mexico, milk is produced mainly in specialized production systems, which depend on irrigated forages such as alfalfa, maize, sorghum and winter cereals to feed livestock. In these systems forage production is limited by low water availability, soil salinity, high ambient temperature and a limited number of forage crops(1). Consequently, it is important to identify alternatives to increase the efficiency of forage production.

The production of forages and bovine milk in the Laguna Region of Mexico are one of the main economic activities of the agricultural sector. Alfalfa is the main protein crop, of which an area of 38,771 ha is harvested throughout the year and to a lesser extent autumn-winter cereals (oats and triticale) in an area of 19,716 ha. Spring and summer crops of maize and sorghum grown in surface areas of 27,344 and 26,251 ha, respectively, produce a major part of the energy and fiber required by cattle(2). Alfalfa, with annual irrigation exceeding $2.0 \mathrm{~m}$ produces yields of often $20 \mathrm{t} \mathrm{ha}^{-1}$ of dry matter (DM) and 4,400 kg ha-1 of crude protein (CP)(3) with water productivity (WP) of $1.18 \mathrm{~kg}$ of DM per $\mathrm{m}^{3}$ of water applied(4). The main cultivation patterns are with annual species with cycles set for spring, summer and autumn-winter. These are with maize-maize-oat and sorghumsorghum-oat, and to a lesser extent maize-oat. The cropping pattern with higher productivity is usually with maize-maize-oat, which produces yields of up to $40 \mathrm{t} \mathrm{ha}^{-1} \mathrm{DM}, 3,689 \mathrm{~kg} \mathrm{ha}^{-1} \mathrm{CP}$ and 234,104 megajoules (MJ) ha-1 of net energy for lactation $\left(\mathrm{NE}_{\mathrm{L}}\right)$, with an irrigation depth similar to alfalfa $(2.0 \mathrm{~m})$. In addition, WP values obtained per $\mathrm{m}^{3}$ were $2.0 \mathrm{~kg} \mathrm{DM}, 0.18 \mathrm{~kg} \mathrm{CP}$ and $11.46 \mathrm{MJ} \mathrm{NE}_{\mathrm{L}}(5)$.

The chemical composition and yield of alternative forage crops such as canola, pea and soybean, suggest that their integration into forage production systems can increase the productivity of these systems, because they can grow up to three crops during the year. Canola produces high quality forage during the autumn- 
y soya, sugieren que su integración en los sistemas de producción de forrajes puede incrementar la productividad de estos sistemas, ya que se pueden realizar hasta tres cultivos durante el año. La canola produce forraje de alta calidad durante el ciclo otoño-invierno en la región, con rendimientos de MS similares o ligeramente menores (10 a $13 \%)$ a los de la avena $\left(7,000\right.$ a $\left.9,980 \mathrm{~kg} \mathrm{ha}^{-1}\right)$; sin embargo, en varios estudios se ha observado consistentemente una mejor composición química del forraje en canola, con una mayor concentración de PC (196.0 a $\left.244.0 \mathrm{~g} \mathrm{~kg}^{-1}\right)$ y menor contenido de fibra detergente neutro (FDN) (347.0 a 398.0 $\mathrm{g} \mathrm{kg}^{-1}$ ), que el obtenido en el forraje de avena, la cual presenta valores de PC de (105.5-134.0 g $\mathrm{kg}^{-1}$ ) y de FDN de $\left(536.0\right.$ a $\left.632.3 \mathrm{~g} \mathrm{~kg}^{-1}\right)(5-8)$. En el ciclo otoño-invierno, el cultivo de chícharo ha alcanzado un potencial de producción de MS hasta de $8,683 \mathrm{~kg}$ ha-1(1), el cual es similar al obtenido en otras partes del mundo $(6,000 \mathrm{a}$ $\left.8,000 \mathrm{~kg} \mathrm{ha}^{-1}\right)^{(9,10)}$. El forraje de chícharo cosechado durante floración e inicio de crecimiento de vainas presenta valores de PC entre 150.0 y $176.0 \mathrm{~g} \mathrm{~kg}^{-1}$ y concentraciones de 490.0 a $526.0 \mathrm{~g} \mathrm{~kg}^{-1}$ de $\operatorname{FDN}(1,5)$.

En el ciclo de primavera-verano, la soya es una alternativa para la producción de forraje en la región debido principalmente a su forraje de alta calidad, con rendimientos de MS de 7,757 a $11,654 \mathrm{~kg}$ ha-1(1,11). Su composición química varía con el genotipo y fase de cosecha, obteniendo valores de PC entre 137.0 y 240.0 $\mathrm{g} \mathrm{kg}^{-1}$, FDN de 308.0 a $501.0 \mathrm{~g} \mathrm{~kg}^{-1(12,13)}$ y $\mathrm{EN}_{\mathrm{L}}$ entre 5.86 y $6.48 \mathrm{MJ} \mathrm{kg}^{-1} \mathrm{MS}(1,5,11)$, con los mejores valores en los genotipos con una mayor proporción de vainas en el forraje $(11,12)$. El objetivo de este estudio fue evaluar el potencial de producción y productividad del agua en patrones de cultivos forrajeros con canola, chícharo y soya integrados como cultivos alternativos.

\section{MATERIALES Y MÉTODOS}

El estudio se realizó de abril de 2009 a abril de 2011 en el Campo Experimental La Laguna del winter in the region, DM yields are similar or slightly lower (10 to $13 \%)$ to oat (7,000 to $\left.9,980 \mathrm{~kg} \mathrm{ha}^{-1}\right)$. However, several studies have consistently shown improved chemical composition of forage in canola, with a higher concentration of CP (196.0 to $244.0 \mathrm{~g} \mathrm{~kg}^{-1}$ ) and lower content of neutral detergent fiber (NDF) (347 to $398 \mathrm{~g} \mathrm{~kg}^{-1}$ ) than that obtained in forage oat, which has CP concentration from 105.5 to $134.0 \mathrm{~g} \mathrm{~kg}^{-1}$ and NDF from 536.0 to $632.3 \mathrm{~g} \mathrm{~kg}^{-1(5-8)}$. In the autumn-winter cycle, forage pea has reached a production potential of DM of up to $8,683 \mathrm{~kg} \mathrm{ha-1(1),} \mathrm{which} \mathrm{is} \mathrm{similar}$ to that obtained in other parts of the world $\left(6,000\right.$ to $\left.8,000 \mathrm{~kg} \mathrm{ha}^{-1}\right)(9,10)$. Forage pea harvested during flowering and pod initiation of growth had values between 150 and $176 \mathrm{~g}$ $\mathrm{kg}^{-1} \mathrm{CP}$ and NDF concentrations of 490 to 526 $\mathrm{g} \mathrm{kg}^{-1}(1,5)$.

In the spring-summer season, soybean is an alternative for forage production in the region mainly due to its high quality forage with DM yields of 7.757 to $11.654 \mathrm{~kg} \mathrm{ha}^{-1}(1,11)$. Its chemical composition varies with genotype and harvest stage, obtaining values between 137.0 and $240.0 \mathrm{~g} \mathrm{~kg}^{-1} \mathrm{CP}, 308.0$ to $501.0 \mathrm{~g} \mathrm{~kg}^{-1}$ $\operatorname{NDF}(12,13)$ and $\mathrm{NE}_{\mathrm{L}}$ between 5.86 and $6.48 \mathrm{MJ}$ $\mathrm{kg}^{-1} \mathrm{DM}(1,5,11)$, with the best values on genotypes with a higher proportion of pods in forage $(11,12)$. The aim of this study was to evaluate the production potential and water productivity in forage cropping patterns with canola, pea and soybean integrated as alternative crops.

\section{MATERIALS AND METHODS}

The study was conducted from April 2009 to April 2011 at La Laguna Experimental Station of the Instituto Nacional de Investigaciones Forestales, Agrícolas y Pecuarias, located in Matamoros, Coahuila, Mexico ( $25^{\circ} 32^{\prime} \mathrm{N}, 103^{\circ}$ $14^{\prime} \mathrm{W}$ and $1,150 \mathrm{~m}$ asl) with soil of clay texture. The experimental site has deep soils $(>1.8 \mathrm{~m})$, with available water values of $150 \mathrm{~mm} \mathrm{~m}^{-1(14)}$ and an organic C content of $0.75 \%(15)$. 
Instituto Nacional de Investigaciones Forestales, Agrícolas y Pecuarias, localizado en Matamoros, Coahuila, México (250 32' N, $103^{\circ} 14^{\prime} \mathrm{W}$ y $1,150 \mathrm{msnm})$, en un suelo de textura arcillosa. El sitio experimental tiene suelos profundos (>1.8 m), con valores de disponibilidad de agua de $150 \mathrm{~mm} \mathrm{~m}^{-1(14)}$ y un contenido de C orgánico de $0.75 \%(15)$.

Se estudiaron cuatro patrones de cultivos alternativos, con especies anuales para los ciclos de primavera, verano y otoño-invierno: maízmaíz-canola; sorgo-sorgo-canola; maíz-maízchícharo; soya-maíz-avena. Los patrones de cultivos testigo fueron: alfalfa (unicultivo); maízavena; maíz-maíz-avena. Se utilizó un diseño experimental de bloques completos al azar con cuatro repeticiones. Las parcelas experimentales fueron de $8 \mathrm{~m}$ de ancho por $5.5 \mathrm{~m}$ de longitud; la parcela útil fue de $15.2 \mathrm{~m}^{2}$ en maíz y sorgo; mientras que en alfalfa, soya, avena, canola y chícharo fue de $12.5 \mathrm{~m}^{2}$.

En primavera, la siembra se hizo en suelo húmedo el 21 de abril en 2009 y el 20 de abril en 2010. La alfalfa se sembró en seco en forma manual en surcos a $0.20 \mathrm{~m}$ el 10 de abril de 2009, con una densidad de $40 \mathrm{~kg} \mathrm{ha}^{-1}$, aplicando el riego de siembra el mismo día y un sobre riego siete días después de la siembra (dds). En maíz y sorgo se utilizó una distancia entre surcos de $0.76 \mathrm{~m}$ y densidades de población de 105,000 y 220,000 plantas ha-1, respectivamente. La soya se estableció en surcos a $0.50 \mathrm{~m}$ y una densidad de población de 600,000 plantas ha-1. Los genotipos utilizados fueron los siguientes: 'CUF-101' en alfalfa, 'Garst 8285 ' en maíz, 'Silo Miel' en sorgo y 'Hutchinson' en soya. En las especies anuales se aplicó un riego de presiembra y cuatro riegos de auxilio a los 32,47 , 63 y 75 dds.

En el primer año, la alfalfa se fertilizó en la siembra con $37 \mathrm{~kg} \mathrm{~N}$ y $40 \mathrm{~kg} \mathrm{P}_{2} \mathrm{O}_{5}$ ha-1, utilizando sulfato de amonio y fosfato mono amónico; se aplicó en la siembra el total de N; posteriormente se aplicaron $40 \mathrm{~kg} \mathrm{P}_{2} \mathrm{O}_{5}$ ha-1 antes de los cortes $2,4,6$ y 8 , utilizando ácido
Four alternative cropping patterns were studied, with annual species for spring, summer and autumn-winter seasons: maize-maize-canola; sorghum-sorghum-canola; maize-maize-pea; maize-soybean-oat. The control cropping patterns were: alfalfa (uniculture); maize-oat; maize-maize-oat. The experimental design used was a complete randomized block with four replications. The experimental plots were $8 \mathrm{~m}$ wide by $5.5 \mathrm{~m}$ in length, the useful plot area was $15.2 \mathrm{~m}^{2}$ in maize and sorghum; while for alfalfa, soybean, oat, canola and pea it was $12.5 \mathrm{~m}^{2}$.

In spring, sowing was done in moist soil on the $21^{\text {st }}$ of April in 2009 and the 20th of April in 2010. The alfalfa was seeded into dry soil manually in rows with $0.20 \mathrm{~m}$ spacing on the $10^{\text {th }}$ of April in 2009, with a seed rate of $40 \mathrm{~kg}$ ha-1, applying irrigation the same day when planting and a light irrigation for $7 \mathrm{~d}$ after sowing (das). For maize and sorghum a row spacing of $0.76 \mathrm{~m}$ was used with population densities of 105,000 and 220,000 plants ha-1, respectively. Soybean was planted at a population density of 600,000 plants ha-1 in rows spaced at $0.50 \mathrm{~m}$. The genotypes used were: 'CUF-101' for alfalfa, 'Garst 8285' for maize, 'Silo Miel' for sorghum and 'Hutchinson' for soybean. For the annual species a pre-plant irrigation and four irrigations at 32, 47, 63 and 75 das were applied.

In the first year, the alfalfa was fertilized at planting with $37 \mathrm{~kg} \mathrm{~N}$ and $40 \mathrm{~kg} \mathrm{P}_{2} \mathrm{O}_{5}$ ha-1 using ammonium sulfate and monoammonium phosphate; all $\mathrm{N}$ was applied at planting, subsequently $40 \mathrm{~kg} \mathrm{P}_{2} \mathrm{O}_{5}$ ha-1 was applied before the cuts 2, 4, 6 and 8, using phosphoric acid as the source. In the second year, the alfalfa was fertilized with $200 \mathrm{~kg} \mathrm{P}_{2} \mathrm{O}_{5}$ ha-1, applying $40 \mathrm{~kg}$ before cutting 10 during the first year and $40 \mathrm{~kg} \mathrm{ha}-1$ before the cuts 2, 4, 6 and 8 of the second year. Plots with maize were fertilized with $248 \mathrm{~kg} \mathrm{~N}$ and $100 \mathrm{~kg} \mathrm{P} \mathrm{O}_{5}$ using ammonium sulfate and monoammonium phosphate; at planting $37 \mathrm{~kg} \mathrm{~N}$ and $100 \mathrm{~kg}$ $\mathrm{P}_{2} \mathrm{O}_{5}$ were applied, subsequently 112 and 99 
fosfórico como fuente. En el segundo año se fertilizó con $200 \mathrm{~kg} \mathrm{P} \mathrm{O}_{5}$ ha-1, aplicando $40 \mathrm{~kg}$ antes del corte 10 del primer año y $40 \mathrm{~kg} \mathrm{ha}^{-1}$ antes de los cortes 2, 4, 6 y 8 del segundo año. En las parcelas con maíz se fertilizó con $248 \mathrm{~kg} \mathrm{~N}$ y $100 \mathrm{~kg} \mathrm{P}_{2} \mathrm{O}_{5}$ ha-1 con sulfato de amonio y fosfato mono amónico, aplicando en la siembra $37 \mathrm{~kg} \mathrm{~N}$ y $100 \mathrm{~kg} \mathrm{P}_{2} \mathrm{O}_{5}$, posteriormente se aplicaron 112 y $99 \mathrm{~kg} \mathrm{~N} \mathrm{ha}^{-1}$ en el primer y segundo riego de auxilio, respectivamente. En soya se utilizó la misma dosis de fósforo que en maíz y $324 \mathrm{~kg} \mathrm{~N}$ ha-1, con $49 \mathrm{~kg} \mathrm{ha-1}$ en la siembra, después se aplicaron 146 y $130 \mathrm{~kg} \mathrm{~N}$ ha-1 en el primero y segundo riego de auxilio, respectivamente. La cosecha de soya se hizo a los 88 dds en la fase del desarrollo R5 (inicio de crecimiento de semillas); el maíz se cosechó a los 90 dds en la fase de un tercio de la línea de leche y en sorgo se realizó a los 92 dds en inicio de espigado. En el primer año de la alfalfa se realizaron nueve cortes a los 67, 97, 125, 157, 199, 271, 314, 356 y 374 dds. En el segundo fueron 11 cortes a los 29, 49, 79, 109, 150, 205, 263, 294, 324, 345 y 373 dds. En este caso se consideró como el inicio del segundo año a partir del 20 de abril de 2010. La cosecha se realizó al inicio de floración o cuando la alfalfa alcanzó una altura de 35 a $40 \mathrm{~cm}$ en periodos de desarrollo lento.

En verano, el híbrido de maíz 'SB-302' se sembró en suelo seco el 1 de agosto en los dos años del estudio. El mismo día se aplicó el riego de siembra para el maíz y rebrote de sorgo 'Silo Miel'; en maíz se aplicó un sobre riego, siete días después de la siembra. Ambos cultivos se establecieron en surcos a $0.76 \mathrm{~m}$, con una densidad de población de 85,000 plantas ha-1 en maíz y el rebrote de sorgo, 174,000 plantas ha-1. Tanto el maíz como el sorgo se fertilizaron con $160 \mathrm{~kg} \mathrm{~N}$ ha-1 y $100 \mathrm{~kg} \mathrm{P}_{2} \mathrm{O}_{5}$ ha-1, utilizando sulfato de amonio y fosfato mono amónico. Se aplicaron en la siembra $37 \mathrm{~kg} \mathrm{~N}$ ha-1, y posteriormente 83 y $40 \mathrm{~kg} \mathrm{~N} \mathrm{ha}^{-1}$ en el primero y segundo riego de auxilio, respectivamente. En los dos cultivos se aplicaron tres riegos de auxilio a los 41,60 y 76 dds. La cosecha en $\mathrm{kg} \mathrm{N} \mathrm{ha-1}$ were applied in the first and second supplementary irrigation, respectively. In soybean the same dose of phosphorus was used

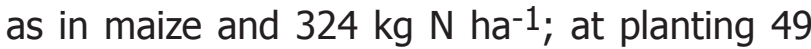
$\mathrm{kg} \mathrm{N} \mathrm{ha}^{-1}$, then 146 and $130 \mathrm{~kg} \mathrm{~N} \mathrm{ha}^{-1}$ were applied in the first and second supplementary irrigation, respectively. The soybean harvest was at 88 das in the development phase R5 (beginning of seed growth); maize was harvested at 90 das in the third milky phase and the sorghum was carried out in 92 das, at the beginning of the heading stage. In the first year of alfalfa nine cuts at $67,97,125,157$, $199,271,314,356$ and 374 das were performed. In the second 11 cuts were done at 29, 49, 79, 109, 150, 205, 263, 294, 324, 345 and 373 das. In this case, the beginning of the second year was considered to begin from April 20,2010 . The harvest took place at the beginning of flowering or when alfalfa reached a height of 35 to $40 \mathrm{~cm}$ during periods of slow development.

In the summer, the maize hybrid 'SB-302' was planted into dry soil on August $1^{\text {st }}$ in the $2 \mathrm{yr}$ of the study. On the same day irrigation was carried out for planting of maize and regrowth of sorghum 'Silo Miel', while for maize a light irrigation was applied for $7 \mathrm{~d}$ after sowing. Both crops were established in rows to $0.76 \mathrm{~m}$, with a population density of 85,000 plants ha-1 for maize and, 174,000 plants ha-1 for sorghum regrowth. Both maize and sorghum were fertilized with $160 \mathrm{~kg} \mathrm{~N}^{-1}$ and $100 \mathrm{~kg} \mathrm{P}_{2} \mathrm{O}_{5}$ ha-1 using ammonium sulfate and monoammonium phosphate. At planting, $37 \mathrm{~kg} \mathrm{~N}$ ha-1 were applied and then 83 and $40 \mathrm{~kg} \mathrm{~N}$ ha-1 were applied in the first and second supplementary irrigation, respectively. In both crops three irrigations were applied at 41, 60 and 76 das. The harvest was conducted for both crops at 100 das, in the third milky phase for maize and the milky-dough grain phase for sorghum.

In the autumn-winter season of 2009-2010 and 2010-2011 oat, canola and pea were planted into dry soil. The oat included in the cropping 
ambos cultivos se realizó a los 100 dds, en la fase de un tercio de la línea de leche en maíz $y$ en grano lechoso-masoso en sorgo.

En el ciclo otoño-invierno 2009-2010 y 20102011 se sembraron en seco los cultivos de avena, canola y chícharo; la avena del patrón con dos cultivos en el año se sembró el 16 de octubre en los dos años; mientras que en los patrones con tres cultivos en el año, las tres especies se sembraron el 3 de diciembre en 2009 y el 26 de noviembre en 2010; sin embargo, la canola y el chícharo fueron dañadas por heladas ocurridas a principios de febrero, por lo que ambos cultivos fueron resembradas el 11 de febrero de 2011. Se utilizaron los genotipos 'Cuauhtemoc' en avena, 'Secada Laguna' en chícharo e 'IMC 205' en canola. La avena se sembró con una sembradora de granos pequeños a una densidad de $140 \mathrm{~kg} \mathrm{ha}^{-1}$, la canola con una sembradora 'Brillion' a una densidad de siembra de $12 \mathrm{~kg} \mathrm{ha}^{-1}$, y el chícharo con una sembradora de botes, dejando una densidad de población de 500,000 plantas ha-1. En todos los cultivos se aplicó una fertilización de $200 \mathrm{~kg} \mathrm{~N}^{-1}$ y $60 \mathrm{~kg}^{-1}$ de $\mathrm{P}_{2} \mathrm{O}_{5}$, utilizando sulfato de amonio y fosfato mono amónico. En la siembra se aplicaron $50 \mathrm{~kg} \mathrm{~N}$ $\mathrm{ha}^{-1} \mathrm{y}$ todo el fósforo; en el primero y segundo riego de auxilio se aplicaron 100 y $50 \mathrm{~kg} \mathrm{~N}$ $\mathrm{ha}^{-1}$, respectivamente.

En los patrones con tres cultivos, en el primer año se aplicó el riego de siembra, un sobre riego y dos riegos de auxilio a los 57 y 82 dds. La cosecha en estos patrones se realizó en floración en canola (103 dds), espigado en avena (104 dds) y en llenado de vainas en chícharo (104 dds). En la avena del patrón con dos cultivos en el año se aplicó el riego de siembra, un sobre riego y tres riegos de auxilio a los 48,85 y 105 dds. La avena se cosechó en la fase de grano lechoso (125 dds). En el segundo año, en todos los cultivos se aplicó un riego de siembra y un sobre riego; posteriormente, en la avena se aplicaron tres riegos de auxilio a los 40, 70 y 92 dds; en canola se aplicaron dos a los 34 y 49 dds; pattern with two crops in a year was planted on $16^{\text {th }}$ of October in both years, while the cropping patterns with three crops in a year were sown on $3^{\text {rd }}$ December 2009 and 26th November 2010. However, canola and pea were damaged by frosts in early February, so both crops were replanted on the $11^{\text {th }}$ of February 2011. The genotypes 'Cuauhtemoc' 'Secada Laguna' and 'IMC 205' were used for oat, pea and canola, respectively. Oat was sown with a seeder for small grains at a seeding rate of 140 $\mathrm{kg} \mathrm{ha}^{-1}$, canola with a 'Brillion' seeder at a seeding rate of $12 \mathrm{~kg} \mathrm{ha}-1$, and pea with a planter pots, at a population density of 500,000 plants ha-1. All crops were fertilized with 200 $\mathrm{kg} \mathrm{N} \mathrm{ha-1}$ and $60 \mathrm{~kg} \mathrm{ha}^{-1}$ of $\mathrm{P}_{2} \mathrm{O}_{5}$, using ammonium sulfate and monoammonium phosphate. At planting $50 \mathrm{~kg} \mathrm{~N} \mathrm{ha}^{-1}$ and all the phosphorus were applied; in the first and second supplementary irrigation 100 and $50 \mathrm{~kg} \mathrm{~N} \mathrm{ha-1}$ were applied, respectively.

In the first year, the cropping patterns with three crops received the planting irrigation, a light watering and two supplementary irrigations at 57 and 82 das. The harvest in these cropping patterns was conducted at flowering stage in canola (103 das), head emergence in oat (104 das) and pod filling in pea (104 das). In oat included in cropping pattern with two crops per year, the irrigation at planting, a light watering and three supplementary irrigations at 48,85 and 105 das were applied. The oat were harvested at the milk stage (125 das). In the second year, in all crops a planting irrigation and a shallow watering was applied; subsequently, in oats three irrigations were applied at 40, 70 and 92 das; in canola two were applied to 34 and 49 das; while for pea three were required at 34, 49 and 67 das. The harvest was performed at 122 das in oat, 67 das in canola and 75 das in pea considering the same growth stages that those of the previous year.

Pest control in maize and sorghum was carried out with two insecticide applications in each growth cycle; Lorsban 480® (Chlorpyrifos ethyl; 
mientras que el chícharo requirió tres, a los 34, 49 y 67 dds. La cosecha se realizó a los 122 dds en avena; 67 dds en canola y 75 dds en chícharo, considerado las mismas fases de desarrollo del año anterior.

El control de plagas en maíz y sorgo se hizo con dos aplicaciones de insecticidas en cada ciclo de crecimiento; a los 20 dds se aplicó Lorsban $480 \AA$ (Clorpirifos etil; 0,0-dietil 0-3,5,6trichloropyridin-2-il fosforotioato) en dosis de $1 \mathrm{~L}$ ha-1 para el control de gusano cogollero (Spodoptera frugiperda). Posteriormente, a los 60 dds se aplicó agromectin 1.8 C.E. \& (Abamectina; Avermectina $\mathrm{B} 1 a C_{48} \mathrm{H}_{72} \mathrm{O}_{14}+$ Avermectina $\mathrm{B} 1 b C_{47} \mathrm{H}_{70} \mathrm{O}_{14}$ ) en dosis de $1.0 \mathrm{~L}$ ha-1 para el control de araña roja (Tetranychus spp). En soya se realizaron dos aplicaciones a los 18 y 56 dds con Endosulfan 35\% C.G. $®$ (Endosulfan; 6,7,8,9,10, 10-hexachloro1,5,5a,6,9,9a-hexahydro-6,9-methano-2,4,3benzodi-oxathiepin3-oxide) en dosis de $1.5 \mathrm{~L}$ ha-1 y Rescate 20 PS® \{Acetamiprid; (E)-N1[(6-chloro-3-pyridyl) methyl]-N2-cyano-N1methylacetamidine $\}$ en dosis de $0.400 \mathrm{~kg}$ ha-1 para controlar mosquita blanca (Bemisia argentifolii Bellows and Perring). En alfalfa, avena y canola se realizó el control del pulgón verde (Acyrthosiphon pisum Harris) y chicharrita verde (Empoasca fabae Harris) con Dimetoato 40 EC\& (Dimetoato; 0,0-dimetil S-metilcarbamoilmetil fosforoditioato) a una dosis de $1.0 \mathrm{~L}$ ha-1; en cada año, en alfalfa se realizaron dos aplicaciones en agosto y octubre, mientras que en avena y canola se realizaron en febrero. En todos los cultivos establecidos en los patrones de cultivo la maleza se controló en forma manual y con azadón.

En la cosecha se determinó en cada cultivo y patrón de especies el rendimiento de materia seca (MS), composición química del forraje y productividad del agua. En composición química del forraje, se determinó fibra detergente neutro (FDN)(16) y N con el método de Kjeldahl(17). Los contenidos de $\mathrm{EN}_{\mathrm{L}} \mathrm{y}$ digestibilidad in vitro (DIV) se estimaron de acuerdo con las metodologías del Consejo Nacional de 0,0-diethyl 0-3,5,6-trichloropyridin-2-il phosphorothioate) was applied for 20 das at $1 \mathrm{~L} \mathrm{ha-1}$ for the control of fall armyworm (Spodoptera frugiperda ). Subsequently, at 60 das 1.8 agromectin C.E. \& (Abamectin; Avermectin $\mathrm{B} \mathrm{aC}_{48} \mathrm{H}_{72} \mathrm{O}_{14}+$ Avermectin $\mathrm{B} 1 b C_{47} \mathrm{H}_{70} \mathrm{O}_{14}$ ) was applied at a dose of $1.0 \mathrm{~L}$ $\mathrm{ha}^{-1}$ for the control of spider mites (Tetranychus spp). In soybean two applications were carried out at 18 and 56 das with Endosulfan 35\% C.G. ${ }^{\circledR}$ (Endosulfan; 6,7,8,9,10, 10-hexachloro1,5,5a,6,9,9a-hexahydro-6,9-methano-2,4,3benzodi-oxathiepin3-oxide) at a dose of $1.5 \mathrm{~L}$ ha-1 and Rescate 20 PS $®$ (Acetamiprid; (E)$\mathrm{N}^{1}$-[(6-chloro-3-pyridyl) methyl]-N2-cyano-N1methylacetamidine) at a dose of $0.400 \mathrm{~kg} \mathrm{ha}-1$ to control whitefly (Bemisia argentifolii Bellows and Perring). In alfalfa, oat and canola to control aphids (Acyrthosiphon pisum Harris) and green leafhopper (Empoasca fabae Harris) Dimethoate 40 ECR (Dimethoate; 0,0-dimethyl S-methylcarbamoylmethyl phosphorodithioate) was applied at a dose of $1 \mathrm{~L} \mathrm{ha}^{-1}$; in each year, in alfalfa two applications were carried out in August and October, while in oat and canola they were conducted in February. In all crops the weeds were controlled manually and with hoe.

At harvest in each crop and cropping pattern the dry matter (DM) yield, chemical composition of forage and water productivity values were determined. For chemical composition of forage, neutral detergent fiber (NDF)(16) and N (Kjeldahl method)(17) concentrations were determined. The contents of $\mathrm{NE}_{\mathrm{L}}$ and in vitro digestibility (IVD) were estimated according to the methodologies of the National Research Council(18). With these data, yields of $C P$, digestible $\mathrm{DM}$ and $\mathrm{NE}_{\mathrm{L}}$ ha-1 were calculated multiplying the content of these nutrients in forage by DM yield for each crop and cropping pattern. The volume of water applied to each cropping pattern was measured by gauging the water flow at the gates of the pipes installed for irrigation and watering time considering each experimental plot. The WP of each cropping pattern was estimated by using the yield of 
Investigación(18). Con estos datos se calcularon los rendimientos de $\mathrm{PC}$, MS digestible y $\mathrm{EN}_{\mathrm{L}}$ ha-1, multiplicando el contenido de estos nutrientes en el forraje con el rendimiento de MS en cada cultivo y patrón. Se midió el volumen de agua aplicada en cada patrón de cultivos, aforando el caudal de agua en las compuertas de los tubos instalados para el riego y considerando el tiempo de riego en cada parcela experimental. La PA en los patrones se estimó con el cociente del rendimiento de MS, $\mathrm{PC}$ y $\mathrm{EN}_{\mathrm{L}}$ entre el volumen total del agua aplicada.

Se realizó un análisis combinado de los datos utilizando un diseño experimental de parcelas divididas, donde las parcelas principales fueron los años y las sub-parcelas los patrones de cultivos. Se hicieron análisis de varianza para los datos de rendimiento, productividad del agua en la producción de materia seca y nutrientes de los cultivos $(P<0.05)$ en los patrones evaluados. Para comparar las medias se utilizó la prueba de la diferencia mínima significativa protegida de Fisher $(P<0.05)$. Los datos se analizaron con el programa estadístico SAS(19).

\section{RESULTADOS Y DISCUSIÓN}

El análisis combinado de los datos indica que en la mayoría de las variables evaluadas la interacción año $x$ patrón de cultivos fue significativa $(P<0.05$; Cuadro 1$)$, por ello los datos se analizaron por año. Las condiciones de clima en los dos años del estudio fueron similares en temperaturas medias, con una mayor precipitación pluvial en la primavera de 2011 (Cuadro 2); sin embargo, el factor de mayor influencia sobre la respuesta de los patrones de cultivo entre años fueron las heladas ocurridas a principios de febrero de 2011 ( -5 a $-10^{\circ} \mathrm{C}$ ), que afectaron los cultivos de canola y chícharo, que tuvieron que resembrarse, en consecuencia los rendimientos de MS se redujeron considerablemente con respecto a los rendimientos del año anterior.
$\mathrm{DM}, \mathrm{CP}$ and $\mathrm{NE}_{\mathrm{L}}$ and dividing it by the total volume of water applied.

A pooled analysis of experimental data was carried out using a split plot design, where the main plots were for years and the sub-plots were for cropping patterns. Analyses of variance were performed for values of yields, and water productivity of dry matter and crop nutrients in cropping patterns evaluated $(P<0.05)$. To compare means, Fisher's protected least significant difference test was performed $(P<0.05)$. Data were analyzed using SAS statistical software(19).

\section{RESULTS AND DISCUSSION}

The combined analysis of experimental data indicates that in most of the variables evaluated the interaction of year $x$ cropping pattern was significant $(P<0.05$; Table 1$)$, hence the data were analyzed by year. Weather conditions in both years of the study were similar in average

Cuadro 1. Valores de probabilidad de un análisis de varianza combinado para rendimientos de materia seca (DM) y nutrientes, además de productividad del agua (WP) en siete patrones de cultivos (Pct) evaluados en dos años

Table 1. Probability values of a combined analysis of variance for yields of dry matter (DM) and nutrients, and water productivity (WP) in seven cropping patterns (Pct) evaluated over a period of two years

\begin{tabular}{lccc}
\hline & \multicolumn{3}{c}{ Significance $(P$-value $)$} \\
\cline { 2 - 4 } & Year & Pct & Year x Pct \\
\hline Total DM yield, kg ha-1 & 0.0107 & 0.0001 & 0.0584 \\
Digestible DM yield, kg ha-1 & 0.8102 & 0.0001 & 0.1085 \\
CP yield, kg ha-1 & 0.0001 & 0.0001 & 0.0001 \\
$\mathrm{NE}_{\mathrm{L}}$ yield, MJ ha-1 & 0.7162 & 0.0001 & 0.1203 \\
WP of total DM, kg m${ }^{-3}$ & 0.0718 & 0.0001 & 0.0117 \\
WP of digestible DM, kg m${ }^{-3}$ & 0.6231 & 0.0001 & 0.0129 \\
WP of CP, $\mathrm{kg} \mathrm{m}^{-3}$ & 0.0001 & 0.0001 & 0.0001 \\
WP of $\mathrm{NE}_{\mathrm{L}}, \mathrm{MJ} \mathrm{m}^{-3}$ & 0.7244 & 0.0001 & 0.0160 \\
\hline
\end{tabular}

$\mathrm{CP}=$ crude protein; $\mathrm{NDF}=$ neutral detergent fiber; $\mathrm{IVD}=$ in vitro digestibility; $\mathrm{NE}_{\mathrm{L}}=$ net energy for lactation. The effects were considered significant when $P<0.05$. 
Composición química del forraje

La alfalfa fue la especie con mejor composición química, con altos valores de DIV, PC y EN, y bajos contenidos de FDN. De las especies convencionales anuales, la mejor concentración energética se observó en maíz (6.53 a 6.95 MJ $\mathrm{kg}^{-1}$ de MS), mientras que la concentración de PC osciló entre 62.7 a $70.3 \mathrm{~g} \mathrm{~kg}^{-1}$. El sorgo registró un contenido similar de $\mathrm{PC}$, un mayor contenido de FDN (641.3 a $708.4 \mathrm{~g} \mathrm{~kg}^{-1}$ ) y un menor contenido de energía que el maíz (5.48 a $5.57 \mathrm{MJ} \mathrm{kg}^{-1}$ de MS). La avena presentó un contenido de PC entre 82 y $99 \mathrm{~g} \mathrm{~kg}^{-1}$, con valores de FDN entre 580.1 y $687.4 \mathrm{~g} \mathrm{~kg}^{-1}$ y una concentración de $\mathrm{EN}_{\mathrm{L}}$ (6.03 a $6.87 \mathrm{MJ}$ $\mathrm{kg}^{-1}$ de MS) ligeramente menor que la del maíz (Cuadro 3).

Los cultivos alternativos canola, chícharo y soya tuvieron mayores contenidos de PC (126.8 a $189.3 \mathrm{~g} \mathrm{~kg}^{-1}$ ) y menores concentraciones de FDN (442.5 a $548.5 \mathrm{~g} \mathrm{~kg}^{-1}$ ) que los observados en el cultivo de avena. El contenido energético en el cultivo de soya fue similar al observado en maíz (6.74 a $6.95 \mathrm{MJ} \mathrm{kg}^{-1}$ de MS), mientras que en los cultivos de canola y chícharo fueron similares o menores a los encontrados en el cultivo se avena (5.48 a $7.03 \mathrm{MJ} \mathrm{kg}^{-1}$ de MS). En relación a la avena, el chícharo presentó temperatures, with greater rainfall in the spring of 2011 (Table 2). However, the most significant factor on the response of cropping patterns between years were frosts in early February $2011\left(-5\right.$ to $\left.-10^{\circ} \mathrm{C}\right)$, affecting crops of canola and pea. Consequently, they had to be replanted and DM yields were reduced significantly compared to the previous year.

\section{Chemical composition of forage}

Alfalfa was the specie with the best chemical composition having high values of IVD, CP and $\mathrm{NE}_{\mathrm{L}}$, and low content of NDF. Of the conventional annual species, the better energy concentration was observed in maize (6.53 to $6.95 \mathrm{MJ} \mathrm{kg}^{-1} \mathrm{DM}$ ), while the concentration of CP was between 62.7 to $70.3 \mathrm{~g} \mathrm{~kg}^{-1}$. Sorghum showed a similar content of $\mathrm{CP}$, higher NDF content (641.3 to $708.4 \mathrm{~g} \mathrm{~kg}^{-1}$ ) and a lower energy content than maize (5.48 to $5.57 \mathrm{MJ}$ $\mathrm{kg}^{-1}$ DM). Oat presented a CP content between 82 and $99 \mathrm{~g} \mathrm{~kg}^{-1}$, with values between 580.1 and 687.4 NDF g kg-1 and $\mathrm{NE}_{\mathrm{L}}$ concentration (6.03 to $6.87 \mathrm{MJ} \mathrm{kg}^{-1} \mathrm{DM}$ ) slightly lower than that of maize (Table 3 ).

The alternative crops canola, pea and soybean had higher contents of CP (126.8 to $189.3 \mathrm{~g}$ $\mathrm{kg}^{-1}$ ) and lower concentrations of NDF (442.5

Cuadro 2. Ciclos de crecimiento y factores climáticos durante el desarrollo de las especies establecidas en los patrones de cultivos evaluados en dos años en la Comarca Lagunera, México

Table 2. Growing seasons and weather factors during the development of the species included in the cropping patterns evaluated over a period of two years in the Comarca Lagunera, Mexico

\begin{tabular}{|c|c|c|c|c|c|c|c|}
\hline \multirow[b]{2}{*}{ Growing season } & \multirow{2}{*}{$\begin{array}{l}\text { Date of } \\
\text { sowing }\end{array}$} & \multirow[b]{2}{*}{ Harvest } & \multirow{2}{*}{$\begin{array}{l}\text { Cycle } \\
\text { (days) }\end{array}$} & \multicolumn{2}{|c|}{ Temperature mean $\left({ }^{\circ} \mathrm{C}\right)$} & \multirow{2}{*}{$\begin{array}{c}\text { Precipitation } \\
\text { accumulated (mm) }\end{array}$} & \multirow{2}{*}{$\begin{array}{c}\text { Potential } \\
\text { evaporation }(\mathrm{mm})\end{array}$} \\
\hline & & & & Maximum & Minimum & & \\
\hline \multicolumn{8}{|l|}{$2009-2010$} \\
\hline Spring & $10 \mathrm{Apr}$. & 20 Jul. & 90 & 34.9 & 20.1 & 40.4 & 471.8 \\
\hline Summer & 1 Aug. & 11 Nov. & 103 & 30.5 & 17.3 & 99.6 & 380.0 \\
\hline Fall-winter & 17 Oct. & 17 Mar. & 152 & 22.6 & 6.8 & 88.2 & 529.1 \\
\hline \multicolumn{8}{|l|}{$2010-2011$} \\
\hline Spring & 20 Apr. & 31 Jul. & 103 & 34.2 & 19.6 & 166.4 & 399.1 \\
\hline Summer & 1 Aug. & 9 Nov. & 100 & 31.8 & 16.5 & 72.2 & 381.8 \\
\hline Fall-winter & 20 Oct. & 19 Apr. & 182 & 27.2 & 6.8 & 0 & 752.8 \\
\hline
\end{tabular}


valores de DIV similares, mientras que en canola se encontraron valores ligeramente menores. En la soya se observaron valores de DIV mayores a los del maíz y similares a los de alfalfa. Los valores más bajos de DIV se presentaron en sorgo. De acuerdo con las características de composición química observadas en el estudio, la canola, chícharo y soya pueden considerarse como forrajes proteicos, con menor contenido fibroso que los forrajes convencionales anuales y con buen valor energético (Cuadro 3).

En el ciclo otoño-invierno, las concentraciones de PC y FDN en el cultivo de canola (Cuadro 3) fueron menores que las registradas en otros estudios en la región, en los que se consignan valores de 196.0 y $240.3 \mathrm{~g} \mathrm{~kg}^{-1}$ de $P C$ y de 390.1 a $429.0 \mathrm{~g} \mathrm{~kg}^{-1}$ en FDN. En contenido energético, los valores de $E N_{L}$ fueron similares entre estudios (5.07 a $\left.6.03 \mathrm{MJ} \mathrm{kg}^{-1} \mathrm{MS}\right)(1,5,8)$. En estudios previos, el forraje de chícharo to $548.5 \mathrm{~g} \mathrm{~kg}^{-1}$ ) than those observed in oat. The energy content in soybean was similar to that observed in maize (6.74 to $6.95 \mathrm{MJ} \mathrm{kg-1}$ DM), whereas in canola and pea were similar or lower than those found in oat (5.48 to 7.03 $\mathrm{MJ} \mathrm{kg}^{-1} \mathrm{DM}$ ). In comparison to oat, IVD of pea presented similar values, whereas canola had slightly lower values. In soybean IVD values were higher than maize and similar to what was found in alfalfa. The lowest values IVD were found in sorghum. According to the characteristics of chemical composition observed in this study, canola, pea and soybean can be considered as protein forages, less fibrous in content than conventional annual forages and with good energy values (Table 3).

In the autumn-winter season, the concentrations of CP and NDF in canola (Table 3) were lower than those reported in other studies in the region, in which values of 196.0 and $240.3 \mathrm{~g}$ $\mathrm{kg}^{-1}$ for CP and 390.1 to $429.0 \mathrm{~g} \mathrm{~kg}^{-1}$ for NDF

Cuadro 3. Composición química del forraje de las especies incorporadas en los patrones de cultivos evaluados en dos años

Table 3. Chemical composition of forage species incorporated into cropping patterns evaluated over a period of two years

\begin{tabular}{lccccc}
\hline Species & Year & $\mathrm{CP}\left(\mathrm{g} \mathrm{kg}^{-1}\right)$ & $\mathrm{NDF}\left(\mathrm{g} \mathrm{kg}^{-1}\right)$ & $\mathrm{IVD}\left(\mathrm{g} \mathrm{kg}^{-1}\right)$ & $\mathrm{NE}_{\mathrm{L}}\left(\mathrm{MJ} \mathrm{kg}^{-1} \mathrm{DM}\right)$ \\
\hline Alfalfa & $2009-2010$ & $208.3+$ & 418.8 & 762.6 & 6.57 \\
& $2010-2011$ & 217.1 & 379.2 & 826.1 & 7.20 \\
\multirow{3}{*}{ Maize } & $2009-2010$ & 70.3 & 649.2 & 727.7 & 6.53 \\
& $2010-2011$ & 62.7 & 556.9 & 781.8 & 6.95 \\
Sorghum & $2009-2010$ & 65.3 & 708.4 & 621.4 & 5.48 \\
\multirow{3}{*}{ Oat } & $2010-2011$ & 52.6 & 641.3 & 635.5 & 5.57 \\
& $2009-2010$ & 99.0 & 687.4 & 674.3 & 6.03 \\
Canola & $2010-2011$ & 82.0 & 580.1 & 770.5 & 6.87 \\
& $2009-2010$ & 159.3 & 466.0 & 710.3 & 6.11 \\
Pea & $2010-2011$ & 126.8 & 504.5 & 651.9 & 5.57 \\
& $2009-2010$ & 132.1 & 548.5 & 638.2 & 5.48 \\
\multirow{2}{*}{ Soybean } & $2010-2011$ & 174.2 & 442.5 & 805.2 & 7.03 \\
& $2009-2010$ & 189.3 & 485.4 & 770.2 & 6.74 \\
\hline
\end{tabular}

$\mathrm{CP}=$ crude protein; $\mathrm{NDF}=$ neutral detergent fiber; $\mathrm{IVD}=$ in vitro digestibility; $\mathrm{NE}_{\mathrm{L}}=$ net energy for lactation; $\mathrm{MJ}=$ megajoules.

$\dagger$ Each value is the weighted average of all plots considering the yield of dry matter (DM) per plot. 
presentó contenidos de PC entre 150 y $176 \mathrm{~g}$ $\mathrm{kg}^{-1}, 490$ a $526 \mathrm{~g} \mathrm{~kg}^{-1}$ de FDN y de 4.77 a $5.23 \mathrm{MJ} \mathrm{kg}-1$ MS en $\mathrm{EN}_{\mathrm{L}}(1,5)$. En el presente estudio, este cultivo presentó concentraciones de PC y FDN similares, y mayores contenidos energéticos que en los trabajos anteriores. Durante el ciclo primavera-verano en la región se ha obtenido en el forraje de soya una composición química con valores entre 137 y $246 \mathrm{~g} \mathrm{~kg}^{-1}$ en PC, de 301 a $403 \mathrm{~g} \mathrm{~kg}^{-1}$ en FDN y de 5.82 a $6.49 \mathrm{MJ} \mathrm{kg}^{-1}$ de $\mathrm{MS}$ en $\operatorname{EN}_{\mathrm{L}}(1,5)$. En este trabajo los contenidos de PC y $\mathrm{EN}_{\mathrm{L}}$ en soya fueron similares a los máximos valores encontrados anteriormente, en tanto que los valores de FDN fueron mayores.

Volumen de agua aplicada y rendimientos de materia seca y nutrientes

En los dos años del estudio, las mayores cantidades de agua por año $(P<0.05)$ se aplicaron en el cultivo de alfalfa con láminas de riego de 2.003 a $2.110 \mathrm{~m}(20,035$ a 21,095 m ha-1), mientras que las menores láminas $(P<0.05)$, de 1.227 a $1.361 \mathrm{~m}(12,268$ a 13,608 $\left.\mathrm{m}^{3} \mathrm{ha}^{-1}\right)$, se aplicaron en el sistema de producción con especies anuales y dos cosechas por año. En los sistemas de producción con tres cosechas por año, en el primer año todos los sistemas recibieron láminas de riego similares $(P>0.05)$, entre 1.750 a $1.763 \mathrm{~m}(17,502 \mathrm{a}$ $\left.17,630 \mathrm{~m}^{3} \mathrm{ha}^{-1}\right)$; mientras que en el segundo, los sistemas con canola recibieron láminas menores $(P<0.05)$, entre 1.660 y $1.723 \mathrm{~m}$ $\left(16,595\right.$ a $\left.17,227 \mathrm{~m}^{3} \mathrm{ha}^{-1}\right)$ debido a que se aplicó un riego menos con respecto a los patrones de cultivo que incluyeron avena $y$ chícharo (Cuadro 4).

Respecto a los patrones de cultivos tradicionales, el integrado por maíz en primavera y en verano, y avena en invierno (maíz-maíz-avena) registró los mayores $(P<0.05)$ rendimientos de MS y $E N_{L}$, mientras que en el cultivo de alfalfa se observó la mayor producción de PC $(P<0.05)$; aunque tuvo desventajas con respecto a los patrones con cultivos anuales en cuanto a la producción de MS y energía $(P<0.05)$ (Cuadros $4,5)$. have been reported. In energy content, $\mathrm{NE}_{\mathrm{L}}$ values were similar between studies (5.07 to $6.03 \mathrm{MJ} \mathrm{kg}-1 \mathrm{DM})(1,5,8)$. In previous studies, pea forage presented $\mathrm{CP}$ values between 150 and $176 \mathrm{~g} \mathrm{~kg}^{-1}, 490$ to $526 \mathrm{~g} \mathrm{~kg}^{-1}$ of NDF and 4.77 to $5.23 \mathrm{MJ} \mathrm{kg}^{-1}$ of $\mathrm{DM}$ in $\mathrm{NE}_{\mathrm{L}}(1,5)$. In the present study, this crop showed similar concentrations of $\mathrm{CP}$ and NDF, and higher energy content than previous works. During the spring-summer season in the region, soybean forage have been obtained with a chemical composition values between 137 and $246 \mathrm{~g} \mathrm{~kg}^{-1} \mathrm{CP}, 301$ to $403 \mathrm{~g}$ $\mathrm{kg}^{-1}$ in NDF and 5.82 to $6.49 \mathrm{MJ} \mathrm{kg}^{-1} \mathrm{DM}(1,5)$ in $\mathrm{NE}_{\mathrm{L}}$. In this study the contents of $\mathrm{CP}$ and $\mathrm{NE}_{\mathrm{L}}$ in soybean were similar to the maximum values found previously, while NDF values were higher.

Volume of water applied and yields of dry matter and nutrients

In the two years of the study, the largest quantities of water per year $(P<0.05)$ were applied to alfalfa with irrigation water depths of 2.003 to $2.110 \mathrm{~m}\left(20,035\right.$ to $21,095 \mathrm{~m}^{3}$ ha-1), while smaller quantities $(P<0.05) 1.227$ to $1.361 \mathrm{~m}\left(12,268\right.$ to $\left.13,608 \mathrm{~m}^{3} \mathrm{ha}^{-1}\right)$ were applied in the cropping pattern with annual species and two harvests per year. In production systems with three harvests per year, in the first year all cropping patterns had similar irrigation water depths ( $P>0.05)$, between 1.750 to $1.763 \mathrm{~m}(17,502$ to 17,630 $\left.\mathrm{m}^{3} \mathrm{ha}^{-1}\right)$. In the second year, cropping patterns with canola received less depths of water $(P<0.05)$, between 1.660 and $1.723 \mathrm{~m}$ $\left(16,595\right.$ to $\left.17,227 \mathrm{~m}^{3} \mathrm{ha}^{-1}\right)$, because one less irrigation was applied with respect to cropping patterns involving oat and pea (Table 4).

Regarding traditional cropping patterns, the treatment composed of maize in spring and summer seasons, and oat in winter (maizemaize-oat) registered the highest $(P<0.05) \mathrm{DM}$ yields and $\mathrm{NE}_{\mathrm{L}}$, whereas alfalfa produced the greatest amount of $\mathrm{CP}(P<0.05)$. Nonetheless alfalfa had disadvantages compared to cropping systems with annual crops in terms of 
Entre los cultivos alternativos integrados en los patrones forrajeros, la canola fue la que mayor impacto tuvo sobre la producción de MS y nutrientes; este comportamiento se puede explicar por la capacidad de la canola para generar rendimientos de MS similares a la avena(8); además presenta una mayor concentración de PC y menor contenido fibroso(5,6,8). El mayor impacto de la canola production of DM and energy $(P<0.05)$ (Tables $4,5)$.

Among the alternative crops integrated into forage cropping patterns, canola had the main impact on DM and nutrients production; this behavior can be explained by the ability of canola to generate DM yields similar to oat(8); also it has a higher concentration of $\mathrm{CP}$ and

Cuadro 4. Volumen de agua aplicada y rendimientos de materia seca total y digestible en siete patrones de cultivos evaluados durante dos años

Table 4. Volume of water applied and yields of total and digestible dry matter obtained in seven cropping patterns evaluated over a period of two years

\begin{tabular}{|c|c|c|c|c|c|c|}
\hline \multirow{2}{*}{$\begin{array}{l}\text { Cropping } \\
\text { patterns }\end{array}$} & \multicolumn{2}{|c|}{$\begin{array}{l}\text { Water applied } \\
\left(\mathrm{m}^{3} \mathrm{ha}^{-1}\right)\end{array}$} & \multicolumn{2}{|c|}{$\begin{array}{l}\text { Yield }\left(\mathrm{kg} \mathrm{ha}^{-1}\right) \\
\text { Total DM }\end{array}$} & \multicolumn{2}{|c|}{$\begin{array}{l}\text { Digestible DM } \\
\left(\mathrm{kg} \mathrm{ha}^{-1}\right)\end{array}$} \\
\hline & $2009-2010$ & $2010-2011$ & $2009-2010$ & $2010-2011$ & $2009-2010$ & $2010-2011$ \\
\hline Alfalfa & 21,095 a & 20,035 a & $21,040 d$ & $23,025 \mathrm{c}$ & $16,044 \mathrm{~d}$ & $19,021 \mathrm{c}$ \\
\hline $\mathrm{Mz}-\mathrm{Ot}$ & $13,608 \mathrm{c}$ & $12,268^{f}$ & $25,480^{c}$ & $24,129 \mathrm{C}$ & $18,122 \mathrm{~cd}$ & 19,834 bc \\
\hline Mz-Mz-Ot & $17,532 \mathrm{~b}$ & $18,282 b$ & $34,866 \mathrm{~b}$ & $33,041 \mathrm{~b}$ & $25,445 \mathrm{~b}$ & 25,657 a \\
\hline Mz-Mz-Cn & $17,502 \mathrm{~b}$ & $17,227 \mathrm{~d}$ & $40,094 a$ & $33,102 \mathrm{~b}$ & 28,817 a & 25,485 a \\
\hline Sr-Sr-Cn & $17,602 \mathrm{~b}$ & $16,595 e$ & $37,024 a b$ & 38,142 a & $23,809 \mathrm{~b}$ & $24,276 \mathrm{a}$ \\
\hline Mz-Mz-Ch & $17,630 \mathrm{~b}$ & $18,172 \mathrm{bc}$ & $33,801 \mathrm{~b}$ & 29,857 b & $24,264 \mathrm{~b}$ & $22,770 \mathrm{ab}$ \\
\hline Sy-Mz-Ot & $17,566 \mathrm{~b}$ & $18,051 \mathrm{c}$ & $28,057 \mathrm{c}$ & $24,446 \mathrm{c}$ & 20,222 c & $18,683 \mathrm{c}$ \\
\hline
\end{tabular}

$\mathrm{DM}=$ dry matter; $\mathrm{Mz}=$ maize; $\mathrm{Ot}=$ oat; $\mathrm{Cn}=$ canola; $\mathrm{Sr}=$ sorghum; $\mathrm{Ch}=$ pea; $\mathrm{Sy}=$ soybean.

abcdf Mean values in each column followed by the same letter are not significantly different (LSD, 0.05).

Cuadro 5. Rendimientos de proteína cruda $(\mathrm{CP})$ y de energía neta para lactancia $\left(\mathrm{NE}_{\mathrm{L}}\right)$ obtenidos en siete patrones de cultivos evaluados en dos años

Table 5. Yields of crude protein $(\mathrm{CP})$ and net energy for lactation $\left(\mathrm{NE}_{\mathrm{L}}\right)$ obtained in seven cropping patterns evaluated over a period of two years

\begin{tabular}{llllll}
\hline & \multicolumn{2}{c}{ Yields CP $\left(\mathrm{kg} \mathrm{ha}^{-1}\right)$} & \multicolumn{3}{c}{$\mathrm{NE}_{\mathrm{L}}\left(\mathrm{MJ} \mathrm{kg}^{-1} \mathrm{MS}\right)$} \\
Cropping patterns & $2009-2010$ & $2010-2011$ & $2009-2010$ & $2010-2011$ \\
\hline Alfalfa & $4,383 \mathrm{a}$ & $4,999 \mathrm{a}$ & $138,541 \mathrm{~d}$ & $165,471 \mathrm{c}$ \\
Mz-Ot & $1,941 \mathrm{~d}$ & $1,786 \mathrm{c}$ & $162,565 \mathrm{~cd}$ & $176,180 \mathrm{bc}$ \\
Mz-Mz-Ot & $2,581 \mathrm{C}$ & $2,156 \mathrm{bc}$ & $228,650 \mathrm{ab}$ & $228,377 \mathrm{a}$ \\
Mz-Mz-Cn & $3,564 \mathrm{~b}$ & $2,484 \mathrm{~b}$ & $255,579 \mathrm{a}$ & $226,137 \mathrm{a}$ \\
Sr-Sr-Cn & $3,294 \mathrm{~b}$ & $2,261 \mathrm{bc}$ & $208,829 \mathrm{~b}$ & $211,743 \mathrm{a}$ \\
Mz-Mz-Ch & $2,657 \mathrm{c}$ & $2,084 \mathrm{bc}$ & $215,591 \mathrm{~b}$ & $201,498 \mathrm{ab}$ \\
Sy-Mz-Ot & $3,261 \mathrm{~b}$ & $2,247 \mathrm{bc}$ & $178,772 \mathrm{c}$ & $165,621 \mathrm{c}$ \\
\hline
\end{tabular}

$\mathrm{Mz}=$ maize; $\mathrm{Ot}=$ oat; $\mathrm{Cn}=$ canola; $\mathrm{Sr}=$ sorghum; $\mathrm{Ch}=$ pea; $\mathrm{Sy}=$ soybean; $\mathrm{MJ}=$ megajoules.

abcd Mean values followed by the same letter in a column are not significantly different (LSD, 0.05). 
ocurrió principalmente cuando se estableció en rotación con maíz y sorgo en primavera y verano. Sin embargo, estos efectos positivos sólo ocurrieron en el año con mejores rendimientos de MS de canola, cuando estos fueron mayores ( 8,551 a 9,424 $\left.\mathrm{kg} \mathrm{ha}^{-1}\right)$ a los de avena $(6,198 \mathrm{~kg} \mathrm{ha-1})$. Bajo estas condiciones, el patrón alternativo maíz-maízcanola fue el sobresaliente, debido a un mayor rendimiento de MS y PC respecto al mejor patrón tradicional (maíz-maíz-avena) $(P<0.05)$; se obtuvieron rendimientos adicionales hasta de 3,899 $\mathrm{kg}$ de MS y $925 \mathrm{~kg} \mathrm{ha}^{-1}$ de PC, lo cual significa un incremento de 10.9 y $34.4 \%$ en la producción de MS y PC, respectivamente, a favor del sistema alternativo (Cuadros 4, 5). Los mayores beneficios con la inclusión de canola en la rotación con maíz, fue debido a la buena composición química (Cuadro 3) y altos rendimientos de MS del maíz, mejorando los rendimientos de MS (Cuadro 4) y PC de los patrones de cultivo alternativos, sin reducir el rendimiento de $E N_{L}$ respecto al patrón testigo (maíz-maíz-avena) (Cuadro 5).

La incorporación de canola en el patrón de cultivo con sorgo en primavera y verano (sorgosorgo-canola) incrementó $(P<0.05)$ la producción de PC en un $27.6 \%$ con respecto al patrón testigo maíz-maíz-avena; la canola en este patrón contribuyó a compensar las bajas concentraciones de nutrientes del sorgo (Cuadro 3 ), de tal forma que los rendimientos de MS digestible (Cuadro 4), PC y EN $\mathrm{L}_{\mathrm{L}}$ del forraje anual fueron similares $(P>0.05)$ o mayores $(P<0.05)$ a los obtenidos con el patrón testigo (Cuadro 5). En comparación al otro patrón alternativo sobresaliente (maíz-maíz-canola), la rotación de canola con sorgo tuvo rendimientos de MS total y PC por hectárea similares $(P>0.05)$, sin embargo sus rendimientos de MS digestible y $\mathrm{EN}_{\mathrm{L}}$ fueron menores (Cuadros 4, 5) en el primer año, debido a una menor digestibilidad y contenido energético del forraje de sorgo respecto a los obtenidos en maíz (Cuadro 3).

En el patrón de cultivos soya-maíz-avena, el rendimiento de PC por hectárea se incrementó lower fiber content $(5,6,8)$. The greatest impact of canola occurred mainly when it was grown in rotation with maize and sorghum in spring and summer. However, these positive effects only occurred in the year with better DM yields in canola, when these were higher $(8,551$ to $\left.9,424 \mathrm{~kg} \mathrm{ha}^{-1}\right)$ compared to oat $(6,198 \mathrm{~kg}$ $\left.\mathrm{ha}^{-1}\right)$. Under these conditions, the cropping pattern of maize-maize-canola was the most outstanding, due to increased DM and CP yields regarding the best traditional cropping pattern (maize-maize-oat) $(P<0.05)$. Additional yields up to $3,899 \mathrm{~kg} \mathrm{DM}$ and $925 \mathrm{~kg} \mathrm{ha}^{-1} \mathrm{CP}$ were obtained, which means an increase of 10.9 and $34.4 \%$ in the production of $\mathrm{DM}$ and $\mathrm{CP}$, respectively, in favor of the alternative system (Tables 4,5 ). The greatest benefits with the inclusion of canola in rotation with maize, was due to good chemical composition (Table 3) and high DM yields of maize, improving DM (Table 4) and CP yields of alternative cropping patterns, without reducing the $\mathrm{NE}_{\mathrm{L}}$ yield with respect to the control cropping pattern (maizemaize-oat) (Table 5).

The inclusion of canola into the cropping pattern with spring and summer sorghum (sorghumsorghum-canola) increased $(P<0.05) \mathrm{CP}$ production by $27.6 \%$ compared with the control cropping pattern maize-maize-oat. Canola in this pattern helped offset the low nutrient concentrations in sorghum (Table 3 ), so that the digestible DM (Table 4), CP and $\mathrm{NE}_{\mathrm{L}}$ yields of annual forage were similar $(P>0.05)$ or greater $(P<0.05)$ than those obtained with the control cropping pattern (Table 5). Compared to the other outstanding alternative cropping pattern (maize-maize-canola), the rotation of canola with sorghum had similar total DM and $\mathrm{CP}$ yields per hectare $(P>0.05)$; however their digestible $\mathrm{DM}$ and $\mathrm{NE}_{\mathrm{L}}$ yields were lower (Tables 4,5 ) in the first year due to lower digestibility and energy content of sorghum forage, compared to those obtained in maize (Table 3 ).

In the cropping pattern maize-soybean-oat, $\mathrm{CP}$ yield per hectare increased by $26.4 \%$ (Table $5)$. However, due to the low DM yields $(8,249$ 
en $26.4 \%$ (Cuadro 5). Sin embargo, debido a los bajos rendimientos de MS $\left(8,249 \mathrm{~kg} \mathrm{ha}^{-1}\right)$ respecto al maíz $\left(17,104 \mathrm{~kg} \mathrm{ha}^{-1}\right)$, los rendimientos de MS total, MS digestible (Cuadro 4) y $E N_{L}$ (Cuadro 5) fueron menores al patrón testigo $(P<0.05)$. El otro patrón de cultivos alternativos con chícharo establecido en rotación con maíz en primavera y verano, no presentó ventajas respecto al patrón testigo maíz-maízavena en términos de rendimientos de MS y nutrientes por hectárea ( $P>0.05)$ (Cuadros 4, 5).

Productividad del agua para la producción de materia seca y nutrientes

En la región la producción de forraje es importante tanto en cantidad como en calidad, realizándose una producción intensiva con el establecimiento de tres cultivos de ciclo anual en el año, y en menor proporción con dos cultivos(20). Los principales patrones de cultivos establecidos para los ciclos de primavera, verano y otoño-invierno son: maíz-maíz-avena, sorgosorgo-avena y maíz-avena $(1,20)$. En el primer año del estudio, cuando el cultivo de canola obtuvo su mayor rendimiento de MS y composición de nutrientes, el patrón de cultivos alternativo maíz-maíz-canola superó en PA al patrón convencional (maíz-maíz-avena) en 15.1, 13.8 y $33.3 \%$ para la producción de MS total, MS digestible y $\mathrm{PC}$, respectivamente $(P<0.05)$. Los valores de la $P A$ para $E N_{L}$ fueron similares entre patrones de cultivos en los dos años de evaluación ( $P>0.05$ ) (Cuadro 6). Debido a que el volumen de agua aplicada total en los dos sistemas de producción indicados arriba fueron similares, las ventajas de PA a favor del patrón maíz-maíz-canola se relacionaron a sus mayores valores en rendimientos de MS, MS digestible y PC $(P<0.05)$ respecto a los obtenidos por el patrón testigo maíz-maíz-avena (Cuadros 4, 5).

En el otro patrón de cultivos sobresaliente, con canola en invierno y sorgo en primavera $y$ verano, la PA para la producción de PC se incrementó en $27.7 \%$ respecto al patrón maízmaíz-avena $(P<0.05)$, y se mantuvieron los valores de PA para la producción de MS total, $\mathrm{kg} \mathrm{ha}^{-1}$ ) compared to maize $\left(17,104 \mathrm{~kg} \mathrm{ha}^{-1}\right)$, total DM, digestible DM (Table 4) and $\mathrm{NE}_{\mathrm{L}}$ yields (Table 5) were less than the control cropping pattern $(P<0.05)$. The other alternative cropping pattern established pea in rotation with maize in spring and summer, had no advantages compared to maize-maize-oat control cropping pattern in terms of DM and nutrients yields per hectare $(P>0.05)$ (Tables 4, 5).

Water productivity for the production of dry matter and nutrients

In the region, forage production is important in terms of both quantity and quality, where an intensive production system has been established with the cultivation of three annual crops in the year, and to a lesser extent with two crops(20). The main cropping patterns established for the growing seasons spring, summer and autumn-winter are maize-maizeoat, sorghum-sorghum-oat and maize-oat $(1,20)$. In the first year of the study, when canola had its greatest DM yield and nutrient composition, the alternative cropping pattern maize-maizecanola surpassed WP of the conventional cropping pattern (maize-maize-oat) at 15.1, 13.8 and $33.3 \%$ for total DM, digestible DM and CP yields, respectively $(P<0.05)$. The values of the WP for $\mathrm{NE}_{\mathrm{L}}$ were similar between cropping patterns in the two years of evaluation ( $P>0.05)$ (Table 6). Because the total volume of water applied in the two production systems listed above were similar, the benefits of WP for maizemaize-canola scheme was related to their higher values in yields of $D M$, digestible $D M$ and $C P$ $(P<0.05)$, than those obtained by the reference standard maize-maize-oat (Tables 4, 5).

In the other outstanding cropping pattern, with canola in winter and sorghum in spring and summer seasons, the WP for the production of $\mathrm{CP}$ increased by $27.7 \%$ compared to maizemaize-oat $(P<0.05)$ cropping pattern, and values of WP remained the same for yields of total DM, digestible DM and $\mathrm{NE}_{\mathrm{L}}(P>0.05)$ (Table 6). For this result, it was fundamental that DM 
MS digestible y $\mathrm{EN}_{\mathrm{L}}(P>0.05)$ (Cuadro 6). En este resultado fue fundamental el mayor rendimiento de MS del sorgo (13,156 a 17,089 $\mathrm{kg} \mathrm{ha-1})$ respecto al maíz $(9,874$ a $11,563 \mathrm{~kg}$ $\mathrm{ha}^{-1}$ ) durante el ciclo de verano, además de la contribución de la canola con un forraje con mayor contenido de PC, menor contenido fibroso $(1,5,6,8)$ y menores requerimientos de lámina de riego $(0.54 \mathrm{~m})$ en comparación a la avena $(0.74 \mathrm{~m})^{(8)}$; estos factores compensaron la menor composición química del forraje de sorgo en términos de concentraciones de PC, DIV y $\mathrm{EN}_{\mathrm{L}}$ (Cuadro 3).

En comparación a la alfalfa y considerando los mejores rendimientos, los patrones alternativos maíz-maíz-canola y sorgo-sorgo-canola obtuvieron el 176 a $191 \%$ en rendimiento de MS total, el 148 a $180 \%$ en rendimiento de MS digestible (Cuadro 4), el 75 a $81 \%$ del rendimiento de $\mathrm{PC}$ ha-1 y el 151 al $184 \%$ en la producción de $\mathrm{EN}_{\mathrm{L}}$ en $\mathrm{MJ} \mathrm{ha}^{-1}$ (Cuadro 5). Estos rendimientos se obtuvieron con un volumen de agua promedio de 17,552 $\mathrm{m}^{3}$ ha-1, en comparación a la alfalfa que requirió 21,095 $\mathrm{m}^{3} \mathrm{ha}^{-1}$. Debido a esto, los patrones alternativos con especies anuales tuvieron valores de PA para la producción de PC similares a la alfalfa yield increased in sorghum $(13,156$ to 17,089 $\mathrm{kg} \mathrm{ha}^{-1}$ ) compared to maize $(9,874$ to 11,563 $\mathrm{kg} \mathrm{ha}^{-1}$ ) during the summer season, in addition to the contribution of canola which provides a forage with higher $\mathrm{CP}$ content, lower fiber content $(1,5,6,8)$ and lower requirements for irrigation $(0.54 \mathrm{~m})$ compared to oat $(0.74$ $\mathrm{m})(8)$. These factors offset lower chemical composition of sorghum forage in terms of concentrations of $\mathrm{CP}, \mathrm{IVD}$ and $\mathrm{NE}_{\mathrm{L}}$ (Table 3).

Compared to alfalfa and considering the best yields, alternative cropping patterns with maizemaize-canola and sorghum-sorghum-canola provided yields 176 to $191 \%$ in total DM, and 148 to $180 \%$ in digestible DM (Table 4), 75 to $81 \%$ the yield of CP ha-1 and 151 to $184 \%$ output of $\mathrm{NE}_{\mathrm{L}}$ in $\mathrm{MJ}^{\mathrm{h}}$ ha-1 (Table 5). These yields were obtained with an average water volume of $17,552 \mathrm{~m}^{3} \mathrm{ha}^{-1}$, compared to alfalfa requiring $21,095 \mathrm{~m}^{3}$ ha-1. Because of this, alternative cropping patterns with annual species had WP values for production CP similar to alfalfa $(P>0.05)$ (Table 6), and higher in yields of total $\mathrm{DM}$, digestible $\mathrm{DM}$ (Table 4) and $\mathrm{NE}_{\mathrm{L}}$ per hectare $(P<0.05)$ (Table 5).

The cropping pattern with two crops in the year presented a WP for the production of DM

Cuadro 6. Productividad del agua en la producción de materia seca (DM) y nutrientes obtenida en siete patrones de cultivos evaluados en dos años

Table 6. Water productivity in the production of dry matter (DM) and nutrients obtained in seven cropping patterns evaluated over a period of two years

\begin{tabular}{|c|c|c|c|c|c|c|c|c|}
\hline \multirow{2}{*}{$\begin{array}{l}\text { Cropping } \\
\text { patterns }\end{array}$} & \multicolumn{2}{|c|}{ Total DM $\left(\mathrm{kg} \mathrm{m}^{-3}\right)$} & \multicolumn{2}{|c|}{ Digestible DM $\left(\mathrm{kg} \mathrm{m}^{-3}\right)$} & \multicolumn{2}{|c|}{$\mathrm{CP}\left(\mathrm{kg} \mathrm{m}^{-3}\right) \ddagger$} & \multicolumn{2}{|c|}{$\mathrm{NE}_{\mathrm{L}}\left(\mathrm{MJ} \mathrm{m}^{-3}\right)$} \\
\hline & $2009-2010$ & $2010-2011$ & $2009-2010$ & $2010-2011$ & $2009-2010$ & $2010-2011$ & $2009-2010$ & 2010-2011 \\
\hline Alfalfa & $1.00 \mathrm{e}$ & $1.15 \mathrm{e}$ & $0.76 \mathrm{~d}$ & $0.95 \mathrm{~d}$ & $0.21 \mathrm{a}$ & $0.25 \mathrm{a}$ & $6.57 \mathrm{~d}$ & $8.26 \mathrm{~d}$ \\
\hline Mz-Ot & $1.87 \mathrm{c}$ & $1.97 \mathrm{~b}$ & $1.33 \mathrm{bc}$ & $1.62 \mathrm{a}$ & $0.14 b$ & $0.15 b$ & $11.95 b$ & $14.35 \mathrm{a}$ \\
\hline Mz-Mz-Ot & $1.99 \mathrm{bc}$ & $1.81 \mathrm{bc}$ & $1.45 \mathrm{~b}$ & $1.40 \mathrm{ab}$ & $0.15 b$ & $0.12 \mathrm{~b}$ & $13.05 a b$ & $12.49 \mathrm{ab}$ \\
\hline $\mathrm{Mz}-\mathrm{Mz}-\mathrm{Cn}$ & $2.29 a$ & $1.92 \mathrm{bc}$ & $1.65 a$ & $1.48 \mathrm{ab}$ & $0.20 \mathrm{a}$ & $0.14 b$ & $14.61 \mathrm{a}$ & 13.12 a \\
\hline Sr-Sr-Cn & $2.10 a b$ & $2.30 \mathrm{a}$ & $1.35 \mathrm{~b}$ & $1.46 \mathrm{ab}$ & $0.19 a$ & $0.14 \mathrm{~b}$ & $11.86 b$ & $12.76 a b$ \\
\hline $\mathrm{Mz}-\mathrm{Mz}-\mathrm{Ch}$ & $1.92 b c$ & $1.64 \mathrm{~cd}$ & $1.38 \mathrm{~b}$ & $1.25 b c$ & $0.15 \mathrm{~b}$ & $0.12 b$ & $12.22 \mathrm{~b}$ & $11.10 \mathrm{bc}$ \\
\hline Sy-Mz-Ot & $1.60 \mathrm{~d}$ & $1.36 \mathrm{de}$ & $1.15 \mathrm{c}$ & $1.04 \mathrm{~cd}$ & $0.19 a$ & $0.12 b$ & $10.18 \mathrm{c}$ & $9.18 \mathrm{~cd}$ \\
\hline
\end{tabular}

$\mathrm{CP}=$ crude protein; $\mathrm{NE}_{\mathrm{L}}=$ net energy for lactation; $\mathrm{Mz}=$ maize; $\mathrm{Ot}=$ oat; $\mathrm{Cn}=$ canola; $\mathrm{Sr}=\mathrm{sorghum} ; \mathrm{Ch}=\mathrm{pea} ; \mathrm{Sy}=\mathrm{soybean}$; $\mathrm{MJ}=$ megajoules.

abcd Mean values followed by the same letter in a column are not significantly different (LSD, 0.05). 
$(P>0.05)$ (Cuadro 6), y superiores en la producción de MS total, MS digestible (Cuadro 4) y $\mathrm{EN}_{\mathrm{L}}$ por hectárea $(P<0.05)$ (Cuadro 5 ).

El patrón con dos cultivos en el año presentó una PA para la producción de MS y nutrientes similar a la obtenida por los patrones con tres cultivos en el año ( $P>0.05$ ) (Cuadro 6); sin embargo sus rendimientos anuales totales fueron inferiores $(P<0.05)$ (Cuadros 4,5$)$. En los patrones con tres cultivos, con la utilización de una lámina de riego extra entre 0.392 y $0.601 \mathrm{~m}\left(3,924\right.$ y $\left.6,014 \mathrm{~m}^{3} \mathrm{ha}^{-1}\right)$, se obtuvieron rendimientos adicionales hasta de 9,386 kg MS ha-1 (Cuadro 4), 640 kg PC ha-1 y 66,085 MJ ha-1 de $\mathrm{EN}_{\mathrm{L}}$ (Cuadro 5).

El contenido de PC en el cultivo de canola (Cuadro 3) fue inferior al obtenido en otros estudios realizados en la región $(1,5,8)$; sin embargo aun así su incorporación en los sistemas forrajeros mostró ventajas en producción y PA en relación a los patrones tradicionales $(P<0.05)$. Por ello, si se obtiene un mayor contenido de PC en el forraje de canola, probablemente se puedan obtener las mismas ventajas o mayores aún con los mismos o menores rendimientos de MS que los patrones tradicionales. Esta situación puede ocurrir, ya que en trabajos anteriores y considerando las condiciones de manejo agronómico, se ha encontrado que los rendimientos de MS en canola son iguales o ligeramente inferiores (20\%) que en avena, pero por lo general el contenido de PC es mayor $(1,5,6,8)$.

Impacto potencial en los sistemas de producción forrajeros

En comparación a la alfalfa, los dos patrones de cultivos con especies anuales sobresalientes (maíz-maíz-canola y sorgo-sorgo-canola), mostraron un menor rendimiento (9 a $24 \%$ ) de PC por hectárea $(P<0.05)$; mientras que el rendimiento de $\mathrm{PC}$ en el mejor patrón tradicional (maíz-maíz-avena) fue $34 \%$ menor (Cuadro 5). Considerando el mismo volumen de agua and nutrients similar to that obtained by patterns with three crops in the year $(P>0.05)$ (Table $6)$. However, their total annual yields were lower $(P<0.05)$ (Tables 4, 5). Patterns with three crops, using extra irrigation water depths between 0.392 and $0.601 \mathrm{~m} \mathrm{(3,924} \mathrm{and} \mathrm{6,014}$ $\mathrm{m}^{3} \mathrm{ha}^{-1}$ ) provided additional yields of up to 9,386 kg ha-1 DM (Table 4), $640 \mathrm{~kg} \mathrm{ha}-1$ CP and 66,085 MJ ha-1 $\mathrm{NE}_{\mathrm{L}}$ (Table 5).

The content of $\mathrm{CP}$ in canola forage (Table 3) was lower than in other studies in the region $(1,5,8)$; but still its incorporation in forage cropping systems showed advantages in production and WP in relation to traditional cropping patterns $(P<0.05)$. Therefore, if a higher protein content in canola forage is obtained, it probably can provide the same benefits or even higher with the same or lower DM yields than traditional patterns. This situation can occur, since in previous works and considering the conditions of agronomic management, it has been found that DM yields in canola are equal or slightly lower (20\%) than oat, but usually the content of $\mathrm{CP}$ is higher $(1,5,6,8)$.

Potential impact on forage production systems Compared to alfalfa, the two outstanding cropping patterns with annual species (maizemaize-canola and sorghum-sorghum-canola) had lower yield (9 to $24 \%$ ) of CP per hectare $(P<0.05)$; while the yield of $\mathrm{CP}$ in the best traditional scheme (maize-maize-oat) was $34 \%$ lower (Table 5). Taking into account the same volume of water used per year in conventional systems it is possible to reduce the area planted for alfalfa, and use the available water to establish greater surface area with cropping patterns of annual species, which have higher WP (Table 6). This would maintain the annual $\mathrm{CP}$ yield and increase yields and WP in the production of total $\mathrm{DM}$, digestible $\mathrm{DM}$ and $\mathrm{NE}_{\mathrm{L}}$.

In this region, the two outstanding alternative cropping patterns found in this study (maizemaize-canola and sorghum-sorghum-canola) can be grown in large areas, since canola can grow 
utilizado por año en los sistemas convencionales, esto significa que es posible reducir la superficie sembrada de alfalfa, y utilizar el agua disponible para establecer mayor superficie con patrones de especies anuales, que presentan mayor PA (Cuadro 6); esto permitiría mantener el rendimiento de PC anual, e incrementar los rendimientos y PA de MS total, MS digestible y EN $N_{L}$.

En esta región, los dos patrones de cultivos alternativos sobresalientes en este estudio (maízmaíz-canola y sorgo-sorgo-canola), se pueden sembrar en amplias áreas de la región, ya que la canola puede establecerse en los mismos suelos y fechas de siembra que la avena, y probablemente en áreas más extensas, ya que la canola tiene una mayor tolerancia a la salinidad (11 dS m-1)(21) que la avena (2.6 dS $\left.\mathrm{m}^{-1}\right)$ (22); la salinización del suelo es un problema creciente en la región debido a la extracción del agua para riego en profundidades cada vez mayores(23). Los cultivos de soya y chícharo producen forraje con buena composición química, pero su aportación en la productividad de los patrones de cultivos fue menor, debido principalmente a los bajos rendimientos de MS comparados con los cultivos convencionales; por lo tanto el establecimiento de estas dos especies es conveniente si se quiere producir forraje con buena composición química en PC, FDN, DIV y EN $N_{L}$ (Cuadro 3).

\section{CONCLUSIONES E IMPLICACIONES}

Con la incorporación de canola en los patrones de cultivo con maíz y sorgo en primavera y en verano (maíz-maíz-canola y sorgo-sorgo-canola), se dispone de sistemas de producción alternativos con potencial para incrementar la productividad en la producción de forraje. Estos sistemas de producción, con un volumen de agua similar o menor al utilizado en el patrón de cultivos convencional (maíz-maíz-avena), permiten incrementar los rendimientos y PA en la producción de PC sin disminuir los rendimientos de $M S$ y $E N_{L}$. En relación a la alfalfa, los sistemas de producción alternativos in the same soil and planting dates as oat, and probably in more areas since canola has a higher tolerance to salinity $\left(11 \mathrm{dS} \mathrm{m}^{-1}\right)^{(21)}$ than oat $\left(2.6 \mathrm{dS} \mathrm{m}^{-1}\right)(22)$. Soil salinization is a growing problem in the region due to the extraction of water for irrigation at ever greater depths(23). Soybean and pea produce forage with good chemical composition, but its contribution to the productivity of cropping patterns was lower, mainly due to the low DM yields compared with conventional crops. Therefore, the establishment of these two species is convenient to produce forage with a good chemical composition in terms of $\mathrm{CP}, \mathrm{NDF}, \mathrm{IVD}$ and $\mathrm{NE}_{\mathrm{L}}$ (Table 3).

\section{CONCLUSIONS AND IMPLICATIONS}

With the incorporation of canola into cropping patterns with maize and sorghum in spring and summer seasons (maize-maize-canola and sorghum-sorghum-canola), an alternative crop production system is available with the potential to increase productivity in the production of forage. These production systems use a volume of water similar to or less than that used in conventional cropping pattern (maize-maizeoat), thus allowing for yields and WP increase in the production of $\mathrm{CP}$ without reducing yields of $D M$ and $N E_{L}$. Regarding alfalfa, the outstanding alternative production systems produce higher yields in $\mathrm{DM}$ and $\mathrm{NE}_{\mathrm{L}}$, reaching 75 to $81 \%$ of the yield per hectare of $\mathrm{CP}$, while only using $83 \%$ of the volume of water required for alfalfa.

\section{ACKNOWLEDGEMENTS}

This study was funded by the Instituto Nacional de Investigaciones Forestales, Agrícolas y Pecuarias.

End of english version 
sobresalientes producen mayores rendimientos de $\mathrm{MS}$ y $\mathrm{EN}_{\mathrm{L}}$, y alcanzan el 75 a $81 \%$ del rendimiento de $\mathrm{PC}$ por hectárea, utilizando el $83 \%$ del volumen de agua requerido por la alfalfa.

\section{AGRADECIMIENTOS}

Este estudio fue financiado por el Instituto Nacional de Investigaciones Forestales, Agrícolas y Pecuarias.

\section{LITERATURA CITADA}

1. Reta-Sánchez DG, Serrato-Corona JS, Figueroa-Viramontes $\mathrm{R}$, Cueto-Wong JA, Berumen-Padilla S, Santamaría-César J. Cultivos alternativos con potencial de uso forrajero en la Comarca Lagunera. Libro Técnico Núm. 3. INIFAP-CIRNOCCELALA; 2008.

2. SAGARPA (Secretaría de Agricultura, Ganadería, Desarrollo Rural, Pesca y Alimentación). Resumen Agrícola de la Región Lagunera. Suplemento Especial 2013. El Siglo de Torreón. Torreón, Coahuila, México; 2014.

3. Reta-Sánchez DG, Figueroa-Viramontes U, Sánchez-Duarte JI, Ochoa-Martínez E, Quiroga-Garza HM, Gaytán-Mascorro A. Patrones de cultivo forrajeros alternativos para una mayor eficiencia de producción y aprovechamiento de los nutrimentos reciclados en las excretas del ganado lechero. Folleto Técnico No. 18. INIFAP-CIRNOC-CELALA; 2011.

4. Quiroga-Garza HM, Faz-Contreras R. Incremento de la eficiencia en el uso del agua por la alfalfa mediante la suspensión de riegos en el verano. Terra Latinoamericana 2008;26:111-117.

5. Reta-Sánchez DG, Figueroa-Viramontes U, Faz-Contreras R, Núñez-Hernández G, Gaytán-Mascorro A, Serrato-Corona JS, Payán-García JA. Sistemas de producción de forraje para incrementar la productividad del agua. Rev Fitotec Mex 2010;33:83-87.

6. Reta-Sánchez DG, Sánchez-Duarte JI, Ochoa-Martínez E, Reyes-González A. Canola, cultivo con potencial para incrementar la productividad forrajera en la Comarca Lagunera Mexicana. Hoard's Dairyman en español 2011;512514.

7. Reta-Sánchez DG, Sánchez-Duarte JI, Ochoa-Martínez E, Reyes-González A, Quiroga-Garza HM, Gaytán-Mascorro A. Validación de canola y chícharo como cultivos forrajeros alternativos para el ciclo otoño-invierno en la Comarca Lagunera. En: Martínez-Ríos JJ et al. editores. XXIII Semana
Internacional de Agronomía. FAZ-UJED. Gómez Palacio, Durango, México. 2011:245-249.

8. Cruz-Chairez JJ, Núñez-Hernández G, Faz-Contreras R, RetaSánchez DG, Serrato-Medina HA. Potencial forrajero y eficiencia de uso del agua de canola (Brassica napus L.) en comparación con cultivos tradicionales en el ciclo de invierno. Agrofaz 2012;12:125-130.

9. Potts MJ. The influence of selected agronomic factor on the yield of forage peas. Grass Forage Sci 1982;37:327-331.

10. ÈupiæT, Popoviæ S, Tucak M, Jukiæ G, Rukavina I. Impact of the semi-leafless field pea on dry matter yield. J Central European Agric 2013;14:102-106.

11. Reta-Sánchez DG, Castellanos-Galván PC, Olague-Ramírez J, Quiroga-Garza HM, Serrato-Corona JS, Gaytán-Mascorro A. Potencial forrajero de cuatro especies leguminosas en el ciclo de verano en la Comarca Lagunera. Rev Mex Cienc Agr 2013;4:659-671.

12. Sheaffer CC, Orf JH, Devine TE, Jewett JG. Yield and quality of forage soybean. Agron J 2001;93:99-106.

13. Nielsen DC. Forage soybean yield and quality response to water use. Field Crops Res 2011;124:400-407.

14. Santamaría-César J, Reta-Sánchez DG., Faz-Contreras R, Orona-Castillo I. Reducción del rendimiento potencial en maíz forrajero en calendarios con tres y cuatro riegos. Terra Latinoamericana 2008;26:235-241.

15. Santamaría-César J, Reta-Sánchez DG, Chávez-González JFJ, Cueto-Wong JA, Romero-Paredes Rubio JI. Caracterización del medio físico en relación a cultivos forrajeros alternativos para la Comarca Lagunera. Libro Técnico Núm. 2. INIFAPCIRNOC-CELALA; 2006.

16. Goering HK, Van Soest PJ. Forage fiber analysis (apparatus, reagents, procedures, and some applications). Handbook 379. USDA-ARS, Washington, DC; 1970.

17. Bremner JM. Nitrogen-total. In: Sparks DL editor. Methods of soil analysis. Madison, WI: SSSA Book Ser 5; 1996:10851121.

18. NRC, National Research Council. Nutrient requirements of dairy cattle. Washington, DC: National Academy Press; 2001.

19. SAS Institute. SAS user's guide. Statistics, version 6.0. 4th. Ed. Cary, NC; 1990.

20. Núñez-Hernández G, Cruz-Cháirez JJ, Iván-Santana O, Rodríguez-Hernández K, Sánchez-Duarte JI, Ochoa-Martínez $\mathrm{E}$, et al. Modelo de procesos para el diagnóstico del uso del agua de riego en la producción de forrajes en explotaciones lecheras del sistema intensivo en ambientes cálido y templado. Agrofaz 2012;12:103-111.

21. Francois, LE. Growth, seed yield, and oil content of canola grown under saline conditions. Agron J 1994;86:233-237.

22. Kotuby-Amacher J, Koenig K, Kitchen B. Salinity and plant tolerance. https://extension.usu.edu/files/publications/ publication/AG-SO-03.pdf; 2000. Accessed Aug 18, 2013.

23. Brouste L, Marlin C, Dever L, González-Barrios JL. Hidroquímica y geoquímica isotópica del manto freático de la Comarca Lagunera (Norte de México). Memorias del 25 aniversario del CENID-RASPA-INIFAP-SAGAR. Gómez Palacio, Dgo., México. 1997:87-100. 